\title{
PENGARUH KUALITAS PELAYANAN TERHADAP KEPUASAN WISATAWAN NUSANTARA KE CURUG LEUWI HEJO, BOGOR PADA ERA NEW NORMAL
}

\author{
Evitauli Pangaribuan $^{1}$, I Ketut Suwena ${ }^{2}$, IGPB. Sasrawan Mananda ${ }^{3}$ \\ Email: evitauli@gmail.com ${ }^{1}$, suwenaketut@unud.ac.id ${ }^{2}$,gusmananda@unud.ac.id ${ }^{3}$ \\ ${ }^{1,2,3}$ Program Studi Industri Perjalanan Wisata, Fakultas Pariwisata, Universitas Udayana
}

\begin{abstract}
Abstarct: Curug Leuwi Hejo is taken from the local Sundanese language which is Curug means waterfall, Leuwi means pond, while Hejo means green. The purpose of this study was to determine the effect of service quality on the satisfaction of domestic tourists visiting Curug Leuwi Hejo, Bogor Regency in the new normal era. The sampling technique used purposive sampling with 100 respondents. The data collection techniques used by observation, interviews, questionnaires, documentation, literature studies, and netnography. The data analysis technique used is mixed methods including qualitative and quantitative descriptive analysis. The results of the research using the $t$ test showed that partially the variables of tangible and empathy have a significant effect on the satisfaction of domestic tourists who visit Curug Leuwi Hejo, Bogor Regency in the new normal era. Meanwhile, the variable reliability, responsiveness, and assurance does not have a significant effect on the satisfaction of domestic tourists visiting Curug Leuwi Hejo, Bogor Regency in the new normal era. Based on the results of the $\mathrm{F}$ test showed that simultaneously service quality has a significant and positive effect on the satisfaction of domestic tourists visiting Curug Leuwi Hejo Bogor Regency in the new normal era with a coefficient of determination of $51 \%$.
\end{abstract}

Abstrak: Curug Leuwi Hejo diambil dari bahasa Sunda dari kata Curug berarti air terjun, leuwi berarti kolam, sedangkan hejo berarti warna hijau. Tujuan dari penelitian ini untuk mengetahui pengaruh kualitas pelayanan terhadap kepuasan wisatawan nusantara yang berkunjung ke Curug Leuwi Hejo Kabupaten Bogor pada era new normal. Teknik penentuan sampel menggunakan purposive sampling dengan 100 orang responden. Teknik pengumpulan data dilakukan dengan: observasi, wawancara, kuesioner, dokumentasi, studi pustaka, dan netnografi. Teknik analisis data yang digunakan adalah mixed methods meliputi analisis deskriptif kualitatif dan kuantitatif. Hasil penelitian menjelaskan bahwa uji t menunjukkan variabel wujud fisik (tangible) dan empati (empathy) memiliki pengaruh signifikan terhadap kepuasan wisatawan nusantara yang berkunjung ke Curug Leuwi Hejo Kabupaten Bogor pada era new normal. Sedangkan pada variabel kehandalan (reliability), daya tanggap (responsivenses), dan jaminan (assurance) tidak memiliki pengaruh yang signifikan terhadap kepuasan wisatawan nusantara yang berkunjung ke Curug Leuwi Hejo Kabupaten Bogor pada era new normal. Hasil uji F menunjukkan bahwa kualitas pelayanan memiliki pengaruh signifikan dan positif terhadap kepuasan wisatawan nusantara yang berkunjung ke Curug Leuwi Hejo Kabupaten Bogor pada era new normal dengan nilai koefisien determinasi sebesar $51 \%$.

Keywords: service quality, tourist satisfaction, curug leuwi hejo, new normal. 


\section{PENDAHULUAN}

Menurut Yoeti (1996:108), daya tarik wisata adalah segala sesuatu yang dapat menarik wisatawan untuk berkunjung pada suatu daerah tujuan wisata, seperti alam, budaya, buatan manusia, maupun manusia. Setiap daerah di Indonesia mempunyai keunikan dan potensi alam yang berbeda-beda. Potensi pariwisata ini meningkatkan minat wisatawan untuk berkunjung ke daerah tujuan wisata tersebut.

Salah satu daerah di Indonesia yang memiliki tingkat kunjungan wisatawan cukup tinggi yaitu Kabupaten Bogor, Provinsi Jawa Barat. Kabupaten Bogor pada tahun 2016 masuk kedalam 10 peringkat tertinggi Indeks Pariwisata Indonesia dan menempati urutan ke sembilan. Diketahui bahwa jumlah kunjungan wisatawan nusantara ke Kabupaten Bogor mengalami fluktuasi. Pada tahun 2015 - 2016 terdapat peningkatan wisatawan sebesar $0,73 \%$. Lalu pada tahun 2017 sempat terjadi penurunan. Menurut Kepala Dinas Kebudayaan dan Pariwisata Kabupaten Bogor, hal tersebut dikarenakan terjadinya kemacetan terutama di kawasan puncak, kenaikan harga tiket daya tarik wisata, dan akses menuju daya tarik wisata yang sulit dilalui wisatawan. Setelah itu, pada tahun 2018 - - 2019 mengalami peningkatan, tetapi pada tahun 2020 kembali terjadi penurunan dikarenakan pandemi COVID-19 yang membatasi pergerakan masyarakat dan mengharuskan tetap berada di rumah jika tidak ada hal yang mendesak.

Menurut Dinas Kebudayaan dan Pariwisata Kabupaten Bogor dalam (Umar Fatih, 2018) menyatakan Kabupaten Bogor memiliki beberapa destinasi unggulan yang dapat diteliti dan dijadikan potensi untuk memajukan nama pariwisata Bogor. Salah satunya yaitu daya tarik wisata Curug. Terdapat 30 Curug atau air terjun yang berada di Kabupaten Bogor, seperti Curug Beret, Curug Kembar batu Layang, Curug Cilember, Curug Ciherang, Curug Barong, dan Curug Leuwi Hejo. Menurut Bapak Pedi selaku Kepala Urusan Bagian Destinasi Wisata, Dinas Kebudayaan dan Pariwisata Kabupaten Bogor mengatakan Curug Leuwi Hejo merupakan Curug yang paling banyak diminati dan dikunjungi oleh wisatawan, karena kebersihan dan kejernihan air kolam yang ada.
Saat ini Curug Leuwi Hejo menjadi salah satu daya tarik wisata di Kabupaten Bogor yang ramai dikunjungi wisatawan. Curug Leuwi Hejo juga menjadi Curug Top Search pada laman pencarian Google. Jumlah kunjungan wisatawan nusantara ke Curug Leuwi Hejo mengalami fluktuasi. Pada tahun 2015 hingga tahun 2017 jumlah kunjungan terus mengalami peningkatan. Akan tetapi pada tahun 2018 terjadi penurunan jumlah kunjungan wisatawan. Berdasarkan wawancara yang dilakukan penulis dengan pihak pengelola yaitu Perum Perhutani KPH Bogor, penurunan disebabkan oleh konflik internal yang terjadi antara Lembaga Masyarakat Desa Hutan (LMDH) dengan Perum Perhutani KPH Bogor sehingga sempat terjadi penutupan sementara wisata Curug Leuwi Hejo. Kemudian pada tahun 2019 kunjungan wisatawan kembali mengalami peningkatan sebesar $20 \%$. Pada tahun 2020 jumlah kunjungan wisatawan ke Curug Leuwi Hejo meningkat secara seginifikan sebesar $73 \%$, disaat tempat wisata lain mengalami penurunan kunjungan wisatawan karena pandemi COVID-19, yang membatasi pergerakan dan aktivitas masyarakat di luar rumah. Hal ini dikarenakan Direktur Kajian Strategis Kementerian Pariwisata dan Ekonomi Kreatif (Kemenparekraf) Wawan Rusiawan mengatakan bahwa destinasi wisata alam akan menjadi primadona pasca Covid-19. (Kompas.com, 2020).

Setelah mengalami penutupan sementara sejak tanggal 30 Maret 2021 akibat pandemi COVID-19, Curug Leuwi Hejo baru dibuka kembali pada tanggal 15 bulan Juni 2020. Hal ini dikarenakan tepat pada tanggal 28 Mei 2020 Pemerintah Pusat melalui Menteri Kepala Bappenas menyatakan akan menjalankan masa new normal, sehingga banyak masyarakat yang mulai berani dan melakukan kegiatan berwisata kembali, dengan harapan daya tarik wisata yang dituju menerapkan program CHSE (Cleanliness, Health, Safety, Environment Sustainability).

Namun Berdasarkan hasil observasi masih terdapat wisatawan yang berkunjung ke Curug Leuwi Hejo tidak menerapkan protokol kesehatan, seperti: tidak menggunakan masker; tidak menerapkan aturan jaga jarak atau physical distancing. Tidak hanya terjadi pada 
wisatawan tetapi petugas yang berjaga terkadang kurang tegas dalam menegur wisatawan yang tidak melakukan prosedur protokol kesehatan. Camat Sukamakmur (Agus Manjar) mengatakan saat itu wisatawan yang datang membeludak, sedangkan jumlah personel terbatas. Wisatawan juga banyak mengeluhkan mengenai harga tiket masuk yang tidak jelas dan harus melakukan pembayaran dua kali.

Penelitian mengenai kualitas pelayanan terhadap kepuasan wisatawan nusantara bertujuan untuk mengungkap dan mengetahui kesesuaian pelayanan yang diharapkan wisatawan nusantara sehingga dari fenomena tersebut penelitian ini penting dilakukan dengan tujuan untuk mengetahui pengaruh variabel wujud fisik (tangible), kehandalan (reliability), daya tanggap (responsiveness), jaminan (assurance), dan empati (emphaty) terhadap kepuasan wisatawan nusantara yang berkunjung ke Curug Leuwi Hejo Kabupaten Bogor pada era new normal. Serta kedua untuk mengetahui pengaruh kualitas pelayanan secara simultan terhadap kepuasan wisatawan nusantara yang berkunjung ke Curug Leuwi Hejo Kabupaten Bogor pada era new normal.

\section{METODE}

Penelitian ini berlokasi di Curug Leuwi Hejo Desa Karang Tengah, Kecamatan Babakan Madang, Kabupaten Bogor, Provinsi Jawa Barat 16830. Alasan dipilihnya lokasi ini dikarenakan Curug Leuwi Hejo merupakan Curug Top Search dalam laman pencarian google, dan pada tahun 2020 mengalami lonjakan kunjungan wisatawan cukup tinggi, tetapi masih terdapat wisatawan yang kurang puas dengan pelayanan yang diberikan oleh petugas setempat.

Variabel-variabel yang digunakan dalam penelitian ini berdasarkan Parasuraman, Zeithaml, dan Berry, 1990:21 (dalam Hardiyansyah 2011:46) untuk variabel kualitas pelayanan meliputi: wujud fisik (tangible), kehandalan (reliability), daya tanggap (responsiveness), jaminan (assurance), dan empati (emphaty). Pada variabel kepuasan wisatawan menggunakan teori dari Irawan, 2008 meliputi perasaan puas, selalu membeli produk, merekomendasikan kepada orang lain, terpenuhinya harapan wisatawan.
Pengumpulan data dalam penelitian ini dilakukan dengan observasi yaitu pengamatan langsung oleh peneliti, wawancara dengan informan pangkal dan informan kunci yakni Bapak Endang selaku staff Perhutani KPH Bogor bagian urusan Wisata, Bapak Tomy Selaku Asisten Perhutani (ASPER) Wilayah Babakan Madang dan Bapak Wawan selaku anggota Lembaga Masyarakat Desa Hutan (LMDH) Wana Sejahtera. Penyebaran kuesioner dilakukan dengan teknik purposive sampling dengan pertimbangan sampel adalah wisatawan nusantara yang pernah berkunjung ke Curug Leuwi Hejo pada era new normal dan menginap atau berada di kawasan Curug Leuwi Hejo Kabupatn Bogor selama 24 jam atau lebih, dengan jumlah sampel sebanyak 100 orang. Studi pustaka dilakukan dengan mencari data melalui buku, referensi-referensi, jurnal dan artikel di internet. Dokumentasi dilakukan dengan dokumen, tulisan angka dan gambar yang memberikan keterangan untuk dapat mendukung penelitian. Serta netnografi, dilakukan dengan bantuan dunia sosial atau media komputer.

Analisis dalam penelitian ini menggunakan mixed methods meliputi analisis deskriptif kualitatif dan kuantitatif. Analisis data deskriptif kualitatif menghasilkan data berupa kata-kata atau deskripsi. Sedangkan analisis deskriptif kuantitatif data berbentuk angka - angka yang diperoleh dari hasil pengukuran atau penjumlahan dengan bantuan program SPSS. Penelitian ini juga menggunakan analisis regresi linier berganda, untuk mendefinisikan hubungan secara matematis antara variabel independen $(\mathrm{X})$ dan variabel dependen $(\mathrm{Y})$.

\section{HASIL}

Curug Leuwi Hejo Kabupaten Bogor merupakan daya tarik wisata alam yang indah, berjarak 10 kilometer dari pusat Kota Bogor. berada di ketinggian sekitar 500- -1000 mdpl. Oleh karena itu, suhu udara di sekitar kawasan wisata ini sejuk dan menyegarkan. Pada pinggir Curug terdapat tebing yang ditumbuhi pohonpohon sehingga terasa asri. Harga tiket masuk yang dikenakan kepada wisatawan sebesar Rp 25.000,00 Adapun Fasilitas-fasilitas sebagai penunjang bagi wisatawan yang berkunjung yaitu tempat parkir, toilet, mushola, warung 
makan/kios, saung, taman, dan camping area/ penginapan.

Adapun bentuk-bentuk pelayanan di Curug Leuwi Hejo yaitu pelayanan ticketing dan Informasi bertujuan untuk memberikan bantuan kepada para wisatawan agar lebih mudah dalam melakukan kegiatan wisata. Pelayanan kebersihan bertujuan untuk membersihkan dan merapihkan fasilitas umum seperti toilet dan taman, serta menjaga kebersihan seluruh kawasan Curug Leuwi Hejo dari sampah bekas aktivitas wisatawan. Pelayanan keselamatan bertujuan untuk menjaga keselamatan wisatawan pada lokasi Curug Leuwi Hejo, dan bantuan dapat langsung dilakukan kepada wisatawan yang mengalami kecelakaan. Pelayanan transportasi bertujuan agar wisatawan yang tidak kuat melakukan trekking menuju Curug atau ingin kembali dari Curug menuju area parkir kendaraan.

Dibukanya kembali Curug Leuwi Hejo di era new normal dengan penerapan program CHSE yaitu, pada Kebersihan (Cleanliness) di Curug Leuwi Hejo disediakaannya tempat cuci tangan, hand sanitizer. Sedangkan penyemprotan cairan disinfektan tidak dapat dilakukan karena daya tarik yang bersifat wisata alam serta untuk menghindari terjadinya pencemaran atau kerusakan pada lingkungan alam. Kesehatan (Health) dilakukan dengan pengecekan suhu tubuh pada wisatawan dan setiap wisatawan wajib menggunakan masker. Keamanan (Safety) dilakukan pembatasan jumlah wisatawan pada daya tarik wisata Curug Leuwi Hejo dengan metode perhitungan Physical Carrying Capacity (PCC). Terdapat satgas COVID-19 Kecamatan Babakan Madang yang rutin melakukan pengecekan pada kawasan wisata Curug Leuwi Hejo, serta dilakukan pemasangan spanduk mengenai $5 \mathrm{M}$ pada pos pintu masuk area Curug. Ramah lingkungan (Environment Sustainability) dilakukan dengan pemisahan hasil sampah yang terbagi menjadi 3 jenis yaitu sampah plastik, sampah kertas, dan sampah daun.

Berdasarkan hasil analisis dapat diketahui bahwa semua instrumen yang terdiri atas lima variabel independent yaitu variabel wujud fisik (tangible), variabel kehandalan (reliability), variabel daya tanggap (responsiveness), variabel jaminan (assurance), dan variabel empati (emphaty). Serta satu variabel dependent yaitu kepuasan dengan total
29 indikator pernyataan yang telah diuji dan valid, karena semua indikator melebihi standar minimal dari koefisien korelasi R-tabel yaitu 0,1966. Berdasarkan hasil pengukuran menyatakan bahwa instrumen dari lima variabel independent dan satu dependent yang digunakan dalam penelitian ini bernilai reliabel, karena semua alphahitung (Cronbach's Alpha) lebih besar dari alpha tabel yaitu 0,600 .

Berdasarkan hasil analisis, hasil uji $\mathrm{t}$ menunjukkan bahwa nilai sig untuk pengaruh X1 dan X5 terhadap Y kurang dari 0,05 dan nilai thitung lebih dari t tabel, maka H1a \& H5a diterima dan H1o \& H5o ditolak, yang berarti terdapat pengaruh X1 (Wujud Fisik) dan X3 (Empati) terhadap Y (Kepuasan Wisatawan). Sementara, hasil uji t menunjukkan bahwa nilai sig untuk pengaruh X2, X3, dan X4 terhadap Y lebih dari 0,05 dan nilai $\mathrm{t}$ hitung kurang dari $\mathrm{t}$ tabel, maka H2a, H3a, \& H4a ditolak dan H2o, H3o, \& H4o diterima, yang berarti tidak terdapat pengaruh X2 (Kehandalan), X3 (Daya Tanggap), dan $\mathrm{X} 4$ (Jaminan) terhadap $\mathrm{Y}$ (Kepuasan Wisatawan).

Berdasarkan pengujian hipotesis keenam (H6) dengan hasil tabel uji F, diketahui nilai signifikansi untuk pengaruh wujud fisik (X1), kehandalan (X2), daya tanggap (X3), jaminan (X4), dan empati (X5) secara simultan terhadap kepuasan wisatawan $(\mathrm{Y})$ adalah sebesar $0,000<$ 0,05 dan nilai $\mathrm{F}$ hitung 19,857 $>\mathrm{F}$ tabel 2,31, sehingga dapat disimpulkan bahwa H6a diterima dan H6o ditolak, yang berarti terdapat pengaruh $\mathrm{X} 1, \mathrm{X} 2, \mathrm{X} 3, \mathrm{X} 4$, dan $\mathrm{X} 5$ secara simultan terhadap $\mathrm{Y}$.

Berdasarkan hasil analisis, menunjukkan bahwa nilai korelasi dari kualitas pelayanan terhadap kepuasan wisatawan yang berkunjung ke Curug Leuwi Hejo Kabupaten Bogor pada era new normal adalah $\mathrm{R}=(0,717)^{2} \times 100 \%$. Melalui hasil analisis tersebut dapat diartikan bahwa sebesar $51 \%$ kepuasan wisatawan yang berkunjung ke Curug Leuwi Hejo Kabupaten Bogor pada era new normal dipengaruhi oleh kualitas pelayanan. Sementara sisanya dipengaruhi oleh variabel lain yang tidak diteliti dalam penelitian ini.

\section{PEMBAHASAN}

Berdasarkan hasil penelitian bahwa wujud fisik (tangible) berpengaruh positif terhadap kepuasan wisatawan nusantara yang berkunjung ke Curug Leuwi Hejo Kabupaten 
Bogor pada era new normal. Hal ini dikarenakan daya tarik wisata menarik dan bersih membuat wisatawan merasa nyaman, memiliki fasilitas yang cukup dalam menunjang kegiatan wisata, dan petugas menerapkan program CHSE (Clean, Health, Safety, Environment sustainability), seperti: pengecekan suhu sebelum masuk kawasan wisata, melakukan cuci tangan atau mengunakan hand sanitizer dan wajib selalu mengenakan masker agar tidak terjadinya penyebaran virus COVID-19 dan tidak terciptanya kluster baru pada daya tarik wisata Curug Leuwi Hejo. Serta pengembangan wisata berbasis ramah lingkungan, (saran Alvin Aditya) yang mengatakan jangan melakukan perubahan terlalu banyak agar tetap terasa asli alamnya.

Pada variabel kehandalan (reliability) tidak berpengaruh terhadap kepuasan wisatawan nusantara yang berkunjung ke Curug Leuwi Hejo Kabupaten Bogor pada era new normal. Hal ini dikarenakan jumlah personel petugas yang kurang sehingga petugas kurang cermat atau teliti dalam memberikan pelayanan kepada wisatawan seperti terkadang wisatawan yang berkunjung tidak mengenakan masker, tetapi petugas tidak menegur. Petugas kurang handal dalam menggunakan alat bantu pelayanan yang saat ini harus digunakan di era new normal yaitu alat cek suhu thermogun. Sesuai saran dari responden bernama Devi, Lusi, dan Charles bahwa "pelayanan yang diberikan oleh petugas harus lebih ditingkatkan terutama di masa pandemi COVID-19, petugas harus lebih memperhatikan dan bertindak tegas kepada wisatawan yang tidak mematuhi pratokol kesehatan".

Pada variabel daya tanggap (responsivenses) tidak berpengaruh terhadap kepuasan wisatawan nusantara yang berkunjung ke Curug Leuwi Hejo Kabupaten Bogor pada era new normal. Hal ini dikarenakan kurangnya jumlah personel petugas sehingga petugas kurang cepat dan tepat dalam memberikan tindakan atau solusi saat terjadi masalah kepada wisatawan. Salah satu masalah yang terjadi yaitu saat wisata alam Curug Leuwi Hejo mengalami peningkatan jumlah kunjungan tahun 2020 lalu sehingga wisatawan berdekatan dan tidak melakukan aturan jaga jarak (physical distancing). Padahal pihak pengelola Perum Perhutani telah mengeluarkan aturan protokol operasional mengenai physical carrying capacity. Sesuai saran dari responden bernama Melaty mengatakan, "Untuk jumlah wisatawan yang datang ke Curug Leuwi Hejo harus dibatasi karena terjadi over carrying capacity sehingga tidak menikmati Curug disana karena sesak dengan pengunjung".

Pada variabel jaminan (assurance) tidak berpengaruh terhadap kepuasan wisatawan nusantara yang berkunjung ke Curug Leuwi Hejo Kabupaten Bogor pada era new normal. Hal ini dikarenakan petugas tidak memberikan jaminan harga yang pasti dan tidak sesuai dengan pelayanan dan fasilitas yang didapatkan oleh wisatawan. Petugas juga tidak memberikan penjelasan terlebih dahulu kepada wisatawan, bahwa harga tiket pada pos pertama merupakan biaya parkir dan masuk dalam pengelolaan pihak swasta investor. Sedangkan pos kedua pembayaran untuk daya tarik wisata alam Curug. Sesuai saran dari responden bernama Melania dan Cika Santi mengatakan "Tiket masuk diharapkan tidak double. Dalam artian pengunjung tidak dua kali masuk dan beli tiket".

Pada variabel empati berpengaruh terhadap kepuasan wisatawan nusantara yang berkunjung ke Curug Leuwi Hejo Kabupaten Bogor pada era new normal. Hal tersebut dikarenakan petugas mengutamakan kepentingan wisatawan: Petugas ramah kepada setiap wisatawan, sopan santun dalam membantu dan memberikan pelayanan kepada setiap wisatawan, melayani wisatawan tanpa bertindak diskriminatif (membeda-bedakan), serta menghargai setiap wisatawan. Sesuai saran dari responden bernama Kurnia yang mengatakan semoga bisa mempertahankan dan meningkatkan kualitas pelayanan yang sekarang.

Secara keseluruhan atau simultan, kualitas pelayanan berpengaruh terhadap kepuasan wisatawan nusantara yang berkunjung ke Curug Leuwi Hejo Kabupaten Bogor pada era new normal. Dengan hasil analisis determinasi atau besarnya nilai pengaruh yaitu $51 \%$. Hasil penelitian ini juga mendukung teori Menurut Kotler, (1997) dalam Wisnalmawati (2005:156), yang menyatakan bahwa kualitas pelayanan harus dimulai dari kebutuhan pelanggan dan berakhir pada persepsi pelanggan. 


\section{SIMPULAN DAN SARAN \\ Simpulan}

Berdasarkan hasil dan pembahasan, dalam penelitian ini dapat ditarik simpulan bahwa:

1. Terdapat pengaruh positif pada variabel wujud fisik (tangible) dan variabel empati (empathy) terhadap kepuasan wisatawan Nusantara yang berkunjung ke Curug Leuwi Hejo Kabupaten Bogor pada era new normal. Nsmun terdapat pengaruh negatif pada variabel kehandalan (reliability), varibel daya tanggap (responsivenses), dan variabel jaminan (assurance) terhadap kepuasan wisatawan nusantara yang berkunjung ke Curug Leuwi Hejo Kabupaten Bogor pada era new normal.

2. Terdapat pengaruh positif kualitas pelayanan terhadap kepuasan wisatawan nusantara yang berkunjung ke Curug Leuwi Hejo Kabupaten Bogor pada era new normal. Adapun besarnya pengaruh kualitas pelayanan terhadap kepuasan wisatawan nusantara yang berkunjung ke Curug Leuwi Hejo Kabupaten Bogor pada era new normal sebesar $51 \%$ diperoleh dari hasil analisis determinasi.

\section{Saran}

Saran yang dapat diberikan dalam penelitian ini adalah:

1. Untuk pihak pengelola agar:

a. Menambah jumlah personel petugas.

b. Menetapkan harga tiket masuk yang pasti dan konsisten agar wisatawan tidak membayar dua kali.

c. Memperbaiki fasilitas-fasilitas penunjang untuk kenyamanan wisatawan.

d. Memberikan pelatihan-pelatihan kepada petugas.

e. Menjaga kebersihan kawasan wisata serta fasilitas yang ada.

f. Mengikuti instruksi kerja protokol kesehatan menerapkan Physical Carrying Capacity (PCC) dengan tegas kepada wisatawan.

g. Melakukan promosi melalui media sosial seperti akun instagram, facebook, maupun tiktok agar Curug Leuwi Hejo lebih dikenal di luar DKI Jakarta, Jawa Barat, dan Tangerang.
2. Peneliti selanjutnya yang akan meneliti Curug Leuwi Hejo dapat melakukan penelitian terkait aksesibilitas menuju Curug Leuwi Hejo dan keadaan pasca pandemi COVID-19. 


\section{Kepustakaan}

Ghozali. 2013. Aplikasi Analisis Multivariate dengan Program IBM SPSS 21 Update PLS Regresi. Semarang: Badan Penerbit Universitas Diponegoro. . 2011. Aplikasi Analisis Multivariate Dengan Program SPSS. Semarang: Badan Penerbit Universitas Diponegoro.

Kementerian Negara Perencanaan Pembangunan Nasional/Bappenas. Jumpa Pers, 28 Mei 2020.

Kementerian Pariwisata dan Ekonomi Kreatif Republik Indonesia: "Model Dan Proses Verifikasi \& Sertifikasi CHSE"

Koentjaraningrat. 1981. Pengantar Ilmu Antropologi. Bandung: Rineka Cipta.

Kotler, Philip dan A.B Susanto. 2005, Manajemen Pemasaran Jasa Di Indonesia, AnalisisPerencanaan, Implementasi dan Pengendalian (Edisi keempat). Jakarta: Salemba Empat.

Parasuraman, valarie A. Zeithmal, Leornard L. Berry, 1990, "Delivering Quality Service : Balancing Customer Perception and Expectations" (The Free Press).

Rai Utama, I.G Bagus dan Mahadewi, E. Ni Made. (2012). Metodologi penelitian Pariwisata \& Perhotelan. Yogyakarta : CV Andi OFFSET.

Ramadhian, Nabilla. 2020. Pasca Pandemi Covid-19, Wisata Alam Bakal Jadi Primadona. [Online] Tersedia di https://travel.kompas.com/read/2020/11 /24/203900127/pasca-pandemi-covid19-wisata-alam-bakal-jadi-primadona [diakses 12 Juni 2021].

Sugiyono. (2016). Metode Penelitian Kuantitatif Kualitataif dan Kombinasi (Mixed Methods). Bandung: Alfabeta. . 2008. Metode Penelitian Kuantitatif Kualitatif dan R\&D. Bandung: ALFABETA.

Sukmadinata, N.S. 2011. Metode Penelitian Pendidikan. Bandung: Remaja Rosadakarya.

Suwena, I Ketut dan Ni Ketut Arismayanti. 2020. Sistem Pariwisata. Denpasar, Bali: Cakra Media Utama.
Suwena, I. K. \& Widyatmaja, I. G. N., 2017. Pengetahuan Dasar Ilmu Pariwisata. Denpasar: Pustaka Larasan.

Ummaroh. (2014). Pengaruh Kualitas Pelayanan Terhadap Kepuasan Konsumen dalam Membentuk Loyalitas Konsumen (Studi Kasus pada PT. TIKI Jalur Nugraha Ekakurir (JNE) di Pademangan Jakarta Utara. Skripsi. Program Sarjana Manajemen. Jakarta: Universitas Pancasila.

Wisnalmawati. 2005. Pengaruh Persepsi Dimensi Kualitas Layanan terhadap Niat Pembelian Ulang. Jurnal Ekonomi dan Bisnis. No. 3 Jilid 10 2005, h. 153165.

Yoeti, Oka A., 1996. Pengantar Ilmu Kepariwisataan. Bandung: Angkasa. 